\title{
PRE-BRASILIANO OROGENIC EVOLUTION IN THE SERIDÓ BELT, NE BRAZIL: CONFLICTING GEOCHRONOLOGICAL AND STRUCTURAL DATA
}

\author{
EMANUEL FERRAZ JARDIM DE SA ${ }^{1,8}$; REINHARDT ADOLFO FUCK ${ }^{2,8}$; MARIA HELENA DE FREITAS \\ MACEDO $^{1,3,8}$; JEAN JACQUES PEUCAT ${ }^{4}$; KOJI KAWASHITA ${ }^{5,8}$ : ZORANO SERGIO DE SOUZA ${ }^{1,6} \&$ \\ JEAN MICHEL BERTRAND
}

\begin{abstract}
RESUMO A Faixa Seridó (Provincia Borborema, NE do Brasil) comprende formafoes supracrustais proterozoicas (o Grupo Seridó), seu embasamento gndissico e plutons granitdides. As intrusoes mais antigas (os ortognaisses $\mathrm{G}_{2}$ ) sao afetadas por uma deformasao tangencial penetrativa (o evento $\mathrm{D}_{2}$ ). A deformação transcorrente brasiliana $\left(\mathrm{D}_{3}\right)$ esta superimposta as estruturas relacionadas ao regime tangencial mais antigo $\left(\mathrm{D}_{2}\right)$, cuja idade absoluta ainda e motive de controve'rsia. Uma datação $\mathrm{Pb} / \mathrm{Pb}$ em zircão de $1,99 \pm 0,01 \mathrm{Ga}$, pela t6cnica de evaporacao, foi obtida em um pluton de augen gnaisses $\mathrm{G}_{2}$, admitido como intrusivo numa formação

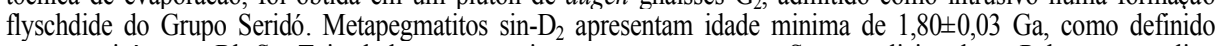
por uma isócrona $\mathrm{Rb}$-Sr. Tais dados sao consistentes com uma orogSnese colisional no Paleoproterozdico $(1,95 \pm 0,05 \mathrm{Ga}$; Jardim de Sd 1994). Por outro lado, datações U-Pb em zircao e idades modelo de Nd, nas supracrustais do Grupo Seridd, indicam uma idade mais jovem, meso a neoproterozdica, para esta unidade (Van Schmus et at 1995a,b), conduzindo a atribuição do evento orogênico colisional ao Ciclo Brasiliano. Ambas as interpretações apresentam pontos conflitantes e questoes nao solucionadas, que deverao ser abordadas por futuras investigações na regiao. De todo modo, a Faixa Seridó e considerada como uma microplaca continental, preservando um registro termotectônico mais antigo, soldada aos terrenes adjacentes num evento orogenico meso ou neoproterozdico.
\end{abstract}

\begin{abstract}
The Seridd Belt (Borborema Province, NE Brazil) comprises Proterozoic supracrustal formations (the Seridó Group), its gneissic basement and granitoid plutons. The older intrusions (the $G_{2}$ orthogneisses) were affected by penetrative tangential deformation ( $\mathrm{D}_{2}$ event). The Brasiliano transcurrent deformation $\left(D_{3}\right)$ overprints structures ascribed to the older $\left(D_{2}\right)$ tangential regime, whose absolute age is still under debate. A $1.99+0.01 \mathrm{Ga} \mathrm{Pb} / \mathrm{Pb}$ zircon evaporation date was obtained from a $\mathrm{G}_{2}$ augen gneiss pluton, thought to be intrusive in a flysch-type formation of the Serido Group. Syn- $\mathrm{D}_{2}$ metapegmatites are at least $1.80 \pm 0.03 \mathrm{Ga}$ old, as defined by a Rb-Sr isochron. Such data are consistent with a late Paleoproterozoic collisional orogeny $(1.95 \pm 0.05 \mathrm{Ga}$ ) in the region (Jardim de Sa 1994). On the other hand, U-Pb zircon and $\mathrm{Nd}$ model dates from Seridó Group supracrustais point to a much younger, Meso- to Neoproterozic age for this unit (Van Schmus et al. 1995a,b), allowing to relate the collisional orogeny to the Brasiliano Cycle. Both interpretations bear conflicting points and still unsolved questions, which will have to be addressed by future investigations in the region. Notwithstanding, the Seridó Belt is regarded as a continental microplate preserving an older thermotectonic imprint, welded to adjacent terranes in a Meso or Neoproterozoic orogenic event.
\end{abstract}

INTRODUCTION Arguments about the age of orogenic structures in the Seridó Belt (NE Brazil) bear important constraints on the nature of the Brasiliano/Pan-African orogeny along the Borborema/Trans-Sahara Belt. This kind of information is essential in order to discuss the relative proportion between accretion of juvenile material and reworking of older crust, or to unravel major differences in crustal evolution between adjacent terranes. Recognition of superimposed orogenic cycles depends on the capability of the continental crust to retain its previous orogenic memory throughout a younger event; this subject remains a major issue concerning the tectonics of deep, ductile domains.

The Brasiliano age of the strike-slip shear zones and associated deformation is well established in NE Brazil. However, different opinions are met when dealing with older structures, generally of tangential style. Correlating these structures with the Brasiliano orogeny, Caby (1989) and Caby et al. (1991) built on models of monocyclic supracrustal belts and widespread nappe tectonics in a late Neoproterozoic Himalayantype collisional setting. On the other hand, Jardim de Sá et al. (1987) and Bertrand \& Jardim de Sá (1990) argued for a pre-Brasiliano, Paleoproterozoic age for these tangential structures and therefore a poly cyclic evolution, at least in some of the supracrustal belts in NE Brazil. Recent data (U-Pb zircon and Nd model dates; Van Schmus et al. 1995a,b) point to a younger, Meso to Neoproterozoic age for the supracrustal sequences in Seridó and elsewhere in the Borborema Province. The evolutionary models based upon these dates are at variance with the former polycyclic models plus a large body of structural and stratigraphic field relations, as discussed in this paper (see also Jardim de Sá 1994).

\footnotetext{
* Apoio FINEP/PADCT, CAPES/COFECUB e Cooperação CEE/Brasil.

1 - Nucleo de Pesquisa/Programa de Pds-Graduação em Geodinamica e Geofísica, Departamento de Geologia, UFRN, Campus, 59.072-970 Natal, RN, Brasil, e-mail: emanuel@geologia.ufrn.br

2 - Institute de Geociências, UnB, 70919-900 Brasflia, DF, Brasil; fax (61)2724286, e-mail: rfuck@guarany.cpd.unb.br

3 - e-mail: mhelena@geologia.ufrn.br

4 - Institut de Geosciences, University de Rennes I, 35042 Rennes Cedex France; fax (99)286780, e-mail: Jean-Jacques.Peucat@univ-rennesl.fr

5 - Centra de Pesquisas Geocronológicas, Institute de Geociências, USP, C.P. 11348, 05422-970 Sao Paulo SP Brasil; fax (11)8183993

6 - e-mail: zorano@geologia.ufrn.br)

7- Centre de Recherches Petrographiques et Géochimiques, CRPG, B.P. 20, 54501 Vandoeuvre les Nancy Cedex France; fax (83)511798, e-mail: bertrand@crpg.cnrs-nancy.fr

8 - Pesquisadores do CNPq.
} 
GEOLOGICAL FRAMEWORK OF THE SERIDÓ

BELT The Serido Belt (SB) is a domain of the Borborema Province. Its southern and western limits are taken, respectively, as the Brasiliano E-W and NE-trending Patos and Portalegre shear zones; fundamental differences in stratigraphy (the nature and age of the supracrustals and intrusive pre-Brasiliano plutons) and structural style are recognized accross these major structures (Jardim de Sá et al. 1992, Jardim de Sá 1994). Towards the coast it is covered by Mesozoic and Cenozoic deposits associated with the Atlantic passive margin.

The following units and tectono-stratigraphic relations are found in the SB (Fig. 1):

(i) High-grade Paleoproterozoic to Archean gneisses and amphibolites of the Caicó Complex represent the oldest unit in the $\mathbf{S B}$ and the basement (with previous, $\mathrm{D}_{1}$ structures) to younger supracrustals;

(ii) The Seridó Group comprises supracrustals mostly in amphibolite facies, displaying the imprint of two major deformation episodes $\left(\mathrm{D}_{2}\right.$ and $\left.\mathrm{D}_{3}\right)$. It is divided in the lower Jucurutu Formation paragneisses and marbles, the Equador Formation quartzites and the upper Seridó Formation micaschists. The latter unit is regarded as a flyschoid turbidite sequence, while the other ones represent shallow water, shelftype deposits.

(iii) The $G_{2}$ orthogneisses correspond to granitoid plutons displaying a penetrative, originally flat-lying fabric;

(iv) The $G_{3}$ granitoids constitute the younger unit, being only affected by the $\mathrm{D}_{3}$ NNE-trending strike-slip shear zones and contemporaneous folding; it corresponds to the Brasiliano plutonism in the SB.

Details about the Neoproterozoic plutons and structures can be found elsewhere (Jardim de Sá et al. 1987, Caby et al. 1991, Archanjo \& Bouchez 1991, Corsini et al. 1991, Jardim de S£ 1994, Corsini 1995). Geological and geochronological data for the Caicó Complex and other high-grade associations is summarized by Souza et al. (1993) and Dantas et al. (1995). The present contribution is especially concerned with contentious aspects such as the structural relations of the $\mathrm{G}_{2}$ orthogneisses and the timing of the tangential deformation, discussing recent geochronological data obtained in the region.

STRUCTURES AND GRANITOID PLUTONS PREDATING THE BRASILIANO TRANSCURRENT DEFORMATION IN THE SERIDÓ BELT Deformation phases in the SB were initially defined and correlated with an early tangential regime $\left(\mathrm{D}_{2}\right)$, later overprinted by strike-slip $\left(\mathrm{D}_{3}\right)$ structures (Jardim de Sa et al. 1987). Caby (1989) and Caby et al. (1991; see also Archanjo \& Bouchez 1991) interpreted the flat-lying (mostly $\mathrm{S}_{2}$ ) and steeply-dipping (mostly 83) foliations as part of the same kinematic regime, representing thrust flats and lateral ramps, or the edges and central parts of flower structures. Although examples of the latter case are now well constrained, the association of $\mathrm{D}_{2}$ and $\mathrm{D}_{3}$ with different kinematic regimes is supported by the following features (Jardim de Sá 1994, Jardim de Sá \& Fuck 1995):

(i) Older, originally flat-lying foliations and the overprinting relations are systematic features not only in the outcrop but also at the regional scale, as demonstrated by structural mapping using Landsat imagery,

(ii) In several localities, successive stretching lineations $\left(\mathrm{L}^{\mathrm{X}} 2\right.$ and $\mathrm{L}^{\mathrm{X}} \mathrm{s}$ ) have different orientations; associated kine- matic markers display mutually incompatible shear sense criteria;

(iii) $\mathrm{D}_{3}$ is associated with a prograde andaluzite-cordierite (or staurolite)-sillimanite low pressure metamorphic regime. $\mathrm{D}_{2}$ structures are associated with relict staurolite-kyanitesillimanite parageneses, which cannot be easily integrated with the $\mathrm{D}_{3}$ low pressure minerals in a single PTt path.

The $\mathrm{G}_{2}$ orthogneisses correspond to an assemblage of strongly deformed porphyritic granites of monzonitic to K-rich calc-alkaline affinities, associated with shoshonitic monzonites, alkaline granites and quartz syenites, and calcalkaline granodiorite-tonalite types. Jardim de Sá (1994; see also Jardim de Sá et al. 1987, 1995a,b) considers these plutons as intrusive in the Seridó Group, as discussed later. On the other hand, these rocks were regarded as anorogenic, synsedimentary intrusions in the Jucurutu Formation (Caby 1989, Caby et al. 1991,1995), mostly based on the assumption that they were not intrusive into the flysch-type metaturbidites (the micaschists of the Seridó Formation, considered to be of Neoproterozoic age by those authors), at the top of the Seridó Group. The lower supracrustal formations (Jucurutu and Equador), cut by these plutons, were interpreted as a Paleoproterozoic platform cover.

In this paper, the status of the $\mathrm{G}_{2}$ suites as synorogenic granitoids is reinforced on the basis of the following evidence (additional details in Jardim de Sá 1994):

(i) The plutons correspond to subhorizontal sheets, controled and/or affected by the tangential $\mathrm{D}_{2}$ structures. Emplacement as shallow sills is not consistent with the lack of volcanic equivalents in the country rocks. Although less frequently, they also intruded the flyschoid micaschists of the Seridó Formation in a few places, as for example to the NE of Cerro Corá (figure 2; photo 1 in plate 1).

(ii) The plutons systematically display homogeneous, strongly penetrative, high temperature S-C fabrics (asymmetric augen structures generally recording top to the south shear sense), best explained by deformation following a decreasing PTt path, typical of cooling syntectonic intrusions (Gapais 1989).

(iii) Associated microgranite or pegmatite sheets are emplaced alongside axial planes of $\mathrm{F}_{2}$ folds in the country rocks and display the corresponding fabrics, an unequivocal evidence of syntectonic intrusions (photos 2, 3 in plate 1).

Besides the $\mathrm{D}_{2}$ structures, an older event $\left(\mathrm{D}_{1}\right)$, restricted to the basement Caicó Complex, is inferred from pre- $\mathrm{D}_{2}$ amphibolite dykes cross-cutting the metamorphic banding $\left(\mathrm{S}_{1}\right)$ in those gneisses, together with previously deformed pebbles in the basal metaconglomerates of the Seridó Group. Field evidence as well as chemical and geochronological data constrain the age of the $\mathrm{D}_{1}$ event around 2.2-2.15 Ga, contemporaneous with widespread calc-alkaline plutonism (Souza et al 1993, Jardim de Sá 1994).

\section{RECENT GEOCHRONOLOGICAL RESULTS AND} THEIR TECTONIC IMPLICATIONS The Paleoproterozoic age of the $\mathrm{D}_{2}$ deformation in the $\mathbf{S B}$ was initially proposed on the basis of $c a$. $2.0 \mathrm{Ga} \mathrm{Rb-Sr}$ poorly defined whole rock isochrons for porphyritic and fine-grained facies of the $\mathrm{G}_{2}$ orthogneisses, assumed to be synorogenic intrusions (Jardim de Sá et al. 1987,1995a,b). The best result so far obtained is the U-Pb zircon age of $1934 \pm 12 \mathrm{Ma}$, reported by Legrand et al. (1991) for a $\mathrm{G}_{2}$ augen gneiss $\mathrm{SE}$ of Açu. Details about analytical data are found in Jardim de Sá (1994). 

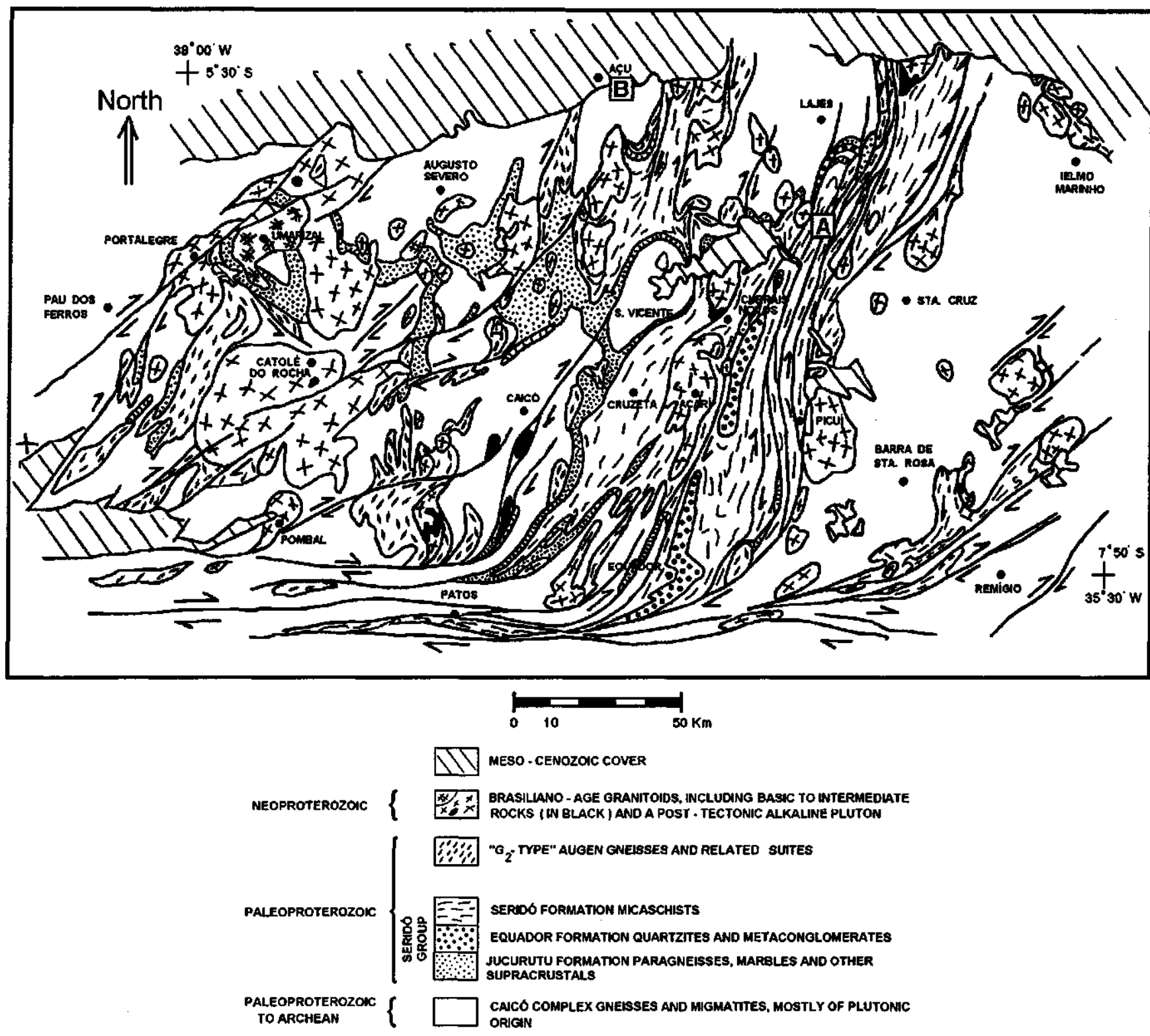

\#

A DATnNe smes

Figure 1 - Simplified geological map of the Seridó Belt, NE Brazil, according to Jardim de Sá (1994).

Figura 1 - Mapa geoló gico simplificado da Faixa Seridó, NE do Brasil, segundo Jardim de Sá (1994).

$\mathrm{Pb} / \mathrm{Pb}$ Zircon Age of a $\mathrm{G}_{2}$ Pluton Intrusive in the Seridó Formation Flyschoid Micaschists in order to test the supposed stratigraphic control of the $\mathrm{G}_{2}$ orthogneisses, argued by Caby (1989) and Caby et al. (1991,1995), a granitic augen gneiss was sampled NE of Cerro Cora (site A in Fig. 1). This pluton (Fig. 2) is in contact with the Seridó micaschists along its western border, where it also truncates, at a low angle, the gradational, interlayered contact of the micaschists with the underlying Jucurutu paragneisses. Although this border of the pluton is reworked by a $\mathrm{D}_{3}$ strike-slip shear zone, outcrops in a lower strain state preserve intrusive relations as shown by apophyses and xenoliths (photo 1 in plate 1). Dating of this pluton is thought to establish a minimum age for the flyschoid deposits that closely predate the $\mathrm{D}_{2}$ deformation.

The zircon concentrate of this sample contains two types of grains: a) automorphic, clear zircons, with or without inclusions and devoid of visible cores, corresponding to magmatic crystals; b) xenomorphic, yellowish brown grains, sometimes with visible overgrowths, interpreted as xenocrysts inherited from a crustal source or contaminant.

The zircons were dated, following the evaporation technique (Köber 1986), at the Institut of Geosciences of the Rennes I University (Fig. 3). Instead of separate single grains, a few crystals of both zircon types had to be used in each of the measurements, due to their very small grain size. In a first heating step (* 1), the averages of $2099 \pm 22 \mathrm{Ma}$, $2048 \pm 20 \mathrm{Ma}$ and $1990 \pm 10 \mathrm{Ma}$ were computed (15 errors are quoted) according to increasing voltage, which is proportional to the energy required to liberate $\mathrm{Pb}$ from the crystal lattices. In a second experiment $(* 2)$, at higher temperatures, the calculated age was $2301 \pm 16 \mathrm{Ma}$. The mixing of phases as expressed by the two populations allows the following interpretation: a) the older dates in the first experiment reflect a 


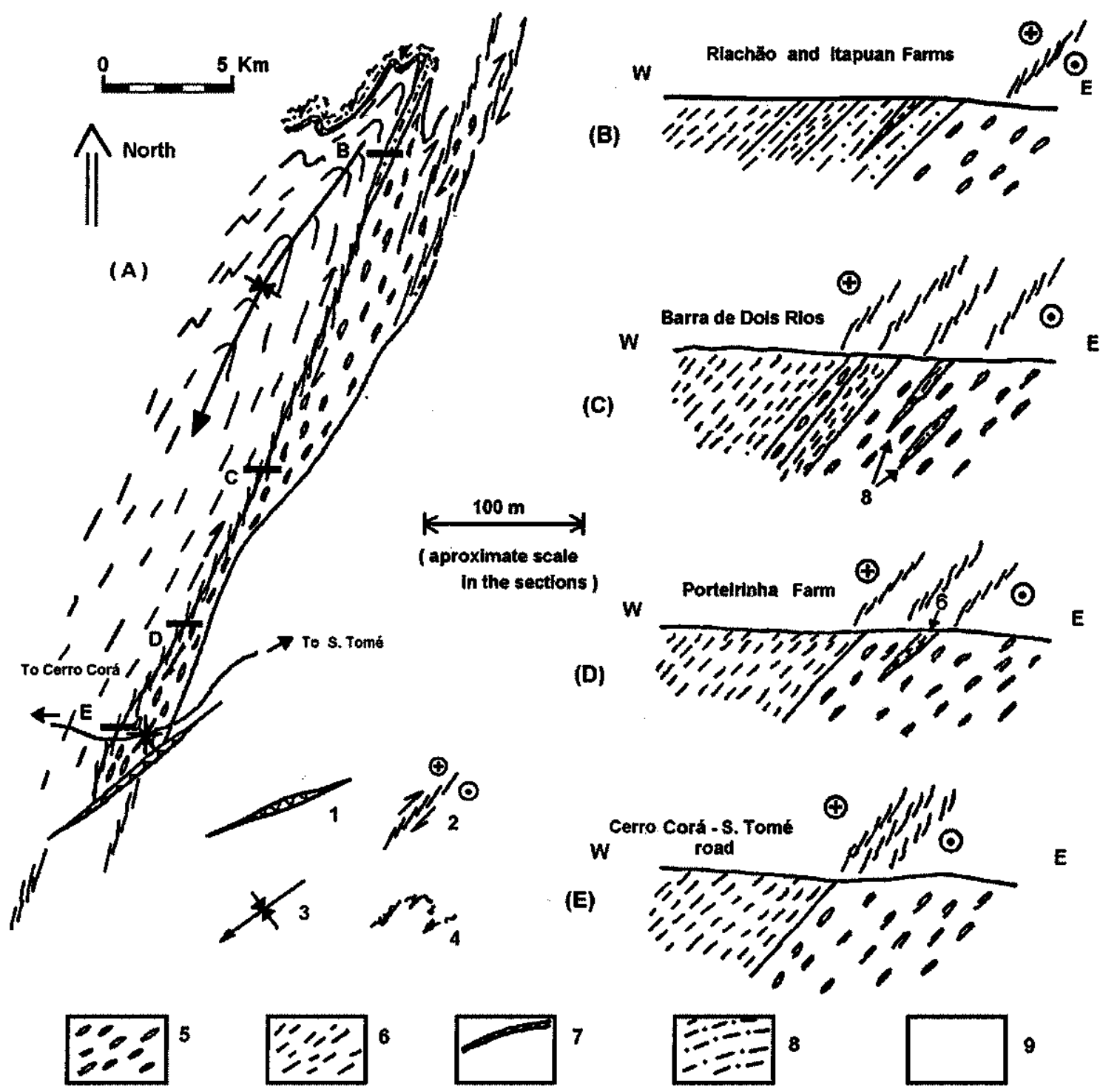

Figure 2 - Contact relations of a $G_{2}$ pluton NE of Cerro Cord town (RN). (A) Geological sketch. To the west, the pluton is in contact with the Seridó orJucurutu Formations, although reworked by a $D_{3}$ mylonitic belt which dies out and steps to the north. The contact (locally interfingering) between these formations is truncated by the pluton in this northern part of the shear zone. The schematic cross sections ( $B$ to E) are located in the map. Ds mylonites were represented in the upper part of the sections, above the corresponding protoliths; note the granitoid apophyses and xenoliths of the metasediments. Symbols: (1) late D fracture and pegmatite; (2) $D_{3}$ strike-slip shear zone; (3) Santa Rosa $D_{3}$ synform; (4) $D_{2}$ thrust; (5) G augen gneiss; (6) Seridó Formation; (7) Equador Formation; (8) Jucurutu Formation; (9) Caicó Complex. The asterisk in the road Cerro Cord to São Tome locates the analysed sample.

Figura 2 - Relações de contato de um pluton $\mathrm{G}_{2}$ a NE de Cerro Corá (RN). (A) Esboço Geológico. O contato oeste do pluton é feito com a Formacao Seridó ou a Formação Jucurutu, sendo retrabalhado por uma faixa de milonitos $\mathrm{D}_{3}$ que termina e é revezada para norte. Nessa área, notar que o contato (interdigitado) entre as formações Jucurutu e Seridó e truncado pelo pluton. Nos perfis esquematicos, os milonitos $\mathrm{D}_{3}$ foram representados na parte superior do corte, acima dos respectivos protdlitos, permitindo visualizar as apdfises do granitoide e os xenó litos dos metassedimentos. Simbologia: (1) fratura e pegmatite tardi- $\mathrm{D}_{3}$; (2) zona de cisalhamento transcorrente $\mathrm{D}_{3}$; (3) sinforme $\mathrm{D}_{3}$ de Santa Rosa; (4) empurrao $\mathrm{D}_{2}$; (5) augen gnaisse $\mathrm{G}_{2}$; (6) Formacao Seridó; (7) Formação Equador; (8) Formacao Jucurutu; (9) Complexo Caicó.

component of radiogenic $\mathrm{Pb}$ extracted from inherited zircon grains, whose crystal lattices have a lower activation energy, due to progressively acummulated radiation dammage; $b$ ) an age $c a$. $2.0 \mathrm{Ga}$ could be inferred for this $\mathrm{G}_{2}$ protolith. This estimate may be slightly high, considering the possibility of a small Pbrad fraction associated with the xenocrysts. In this case, the younger date $(1990 \pm 10 \mathrm{Ma})$ is preferentially retained, being more compatible with the U-Pb age reported by Legrand et al, (1991) in the pluton SE of Açu. A Paleoproterozoic age for the Seridó Group flyschoid turbidites may thus be inferred from this result; c) the older, $2.3 \mathrm{Ga}$ date reflects the radiogenic $\mathrm{Pb}$ component associated with the xenocrysts nuclii, which are better preserved from the isotope loss and reequilibria phenomena which took place during their incorporation within the granitic magma. This age corroborates the ones already reported for the Caicó Complex (Souza et al. 1993, Van Schmus et al. 1995a, Dantas et al. 1995).

Rb-Sr Dating of $\mathbf{G}_{2}$-Type Metapegmatites Aplitic, fine-grained or pegmatitic sheets, as well as local mobilizates, 
are frequently found intrusive alongside the axial surfaces of $\mathrm{F}_{2}$ recumbent folds, bearing the $\mathrm{S}_{2}+\mathrm{L}_{2}^{\mathrm{X}}$ fabric. Based on this structural signature, these rocks can be correlated with the $G_{2}$ suites. To the E/SE of Acu (site $\mathbf{B}$ in Fig. 1; photo 2 in plate 1), metapegmatites with such relations were sampled in adjacent outcrops of the Caicó gneisses. Individual 20 to $25 \mathrm{~kg}$ of whole rock samples were taken, due to their very coarse grain size. In all cases, the pegmatite sheets truncate the older $\mathrm{Si}$ banding of the gneisses and display a penetrative, high temperature $D_{2}$ fabric characterized by the ductile behavior of the feldspars. $\mathrm{D}_{3}$ deformation in this region was relatively weak, as indicated by the open style of $\mathrm{F}_{3}$ folds, with accompanying metamorphic conditions at high greenschist to low amphibolite facies. Post- $\mathrm{D}_{2}$ unmixing textures in the pegmatites, especially perthites and myrmekites, can be related to this younger deformation event. Rb-Sr and complementary $\mathrm{K}-\mathrm{Ar}$ dating was performed at the Centro de Pesquisas Geocronologicas of the University of São Paulo.

Even though being very heterogeneous, five out of eight pegmatite samples are well-aligned along a $1799 \pm 30 \mathrm{Ma}$ isochron, with $\mathrm{Is}_{\mathrm{r}}=0.7063 \pm 4$ and $\mathrm{MSWD}=3.5$ (Fig. 4; la errors are quoted). This figure is regarded as a minimum age estimate for the intrusion of the pegmatite and its deformation in the $\mathrm{D}_{2}$ event. When compared with a nearby $1934 \pm 12 \mathrm{Ma}$ old augen gneiss, the younger age value of the metapegmatite isochron and the scatter of the remaining three analytical points may be explained as the effect of $\mathrm{D}_{3}$ and/or $\mathrm{D}_{2}$. A K-Ar date on a muscovite concentrate indicates an age of $494 \pm 13$ Ma (Jardim de Sá 1994), confirming the late Neoproterozoic reheating. On the other hand, a two-point Rb-Sr isochron calculated with the whole rock + muscovite pair is $1.0 \mathrm{Ga}$ old, and the same value is obtained for the muscovite, assuming any Isr ratio between 0.7 and 1.0. The latter figures are difficult

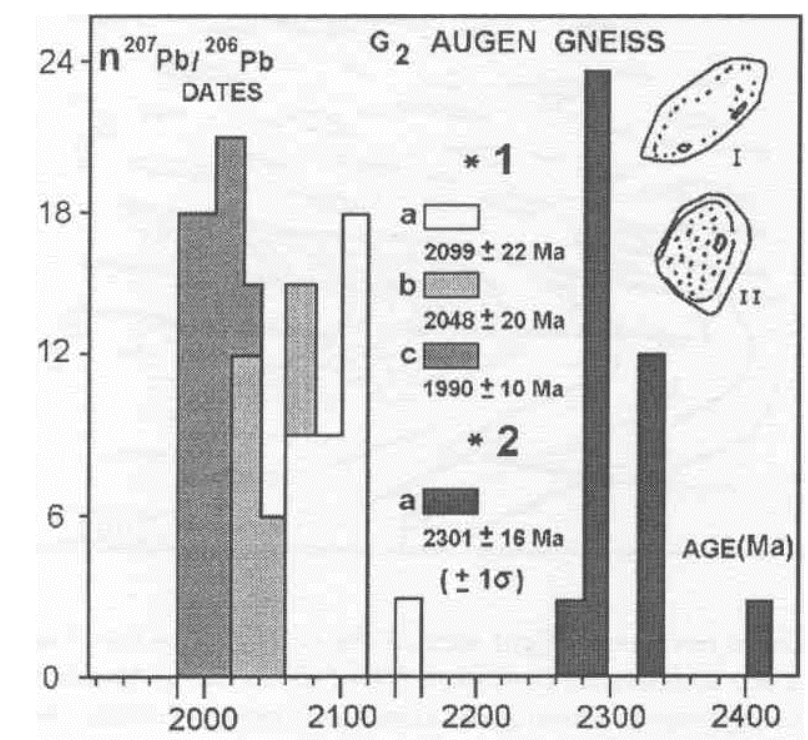

Figure 3 - $\mathrm{Pb} / \mathrm{Pb}$ evaporation zircon dates of the $G_{2}$ augen gneiss NE of Cerro Cord (RN). Type I crystals are euhedral, limpid, with or without inclusions and devoided of visible nucleii, being ofmagmatic origin. Type II zircons are anhedral or subhedral, yellowish and present visible overgrowths, being interpreted as xenocrysts.

Figura 3 - Idades $\mathrm{Pb} / \mathrm{Pb}$ pela tecnica de evaporação do augen gnaisse a NE de Cerro Corá (RN). Os cristais tipo I são euedrais, límpidos, com ou sem inclusoes e desprovidos de nucleos visíveis, sendo de origem magmatica. Os zircoes tipo II são anedrais ou subedricos, amarelados e apresentam sobrecrescimentos visíveis, sendo interpretados como xenocristais. to explain assuming a Brasiliano age for the $\mathrm{D}_{2}$ deformation and metamorphism, as the strong dynamic recrystallization associated with this event must have completely reset the muscovite isotope system. The $1.0 \mathrm{Ga}$ mineral dates are thus consistent with an older, pre-Brasiliano age for $\mathrm{D}_{2}$, coupled with syn to late- $\mathrm{D}_{3}$ reheating, perthitization and other unmixing textures of the K-feldspars, leading to the isotope disequilibria observed in these systems. The mineralogy of the rock offers few sites for retention of radiogenic $\mathrm{Sr}$ liberated from their crystal lattices (Moorbath \& Taylor 1985). This is also reflected in the rock's bulk composition; for instance, the two most discrepant whole rock samples in Fig. 5 have less than $70 \mathrm{ppm}$ of $\mathrm{Sr}$, while the other ones display values between 107 and $471 \mathrm{ppm}$. In any case, even if not precise, and interpreted either as a magmatic or a deformational age, the metapegmatite isochron militates against correlation of $\mathrm{D}_{2}$ with the Brasiliano orogeny.

\section{U-Pb Zircon and Nd Model Dates of Seridó Group Supracrustals (Van Schmus et al. 1995a,b)}

Recent U-Pb zircon data on a high-grade Jucurutu paragneiss was interpreted (Van Schmus et al. 1995a,b) as reflecting detrital grains (and therefore, a maximum sedimentation age), inherited from sources $c a$. $2.15 \mathrm{Ga}$ and $1.75 \mathrm{Ga}$ old; $\mathrm{Nd}$ model $\left(\mathrm{T}_{\mathrm{DM}}\right)$ dates from these metasediments vary from 2.6 to 2.4 $\mathrm{Ga}$. Elsewhere, Nd model dates obtained from Jucurutu Formation paragneisses and Seridó Formation micaschists are in the range 1.6 to $1.2 \mathrm{Ga}$. Van Schmus et al. (1995b) also reported $\mathrm{U}-\mathrm{Pb}$ zircon dates from the Seridó micaschists and felsic rocks interpreted as interlayered volcanics, suggesting contributions from a source and/or volcanic detritus not older than 0.8-0.7 Ga. Such results lead those authors to ascribe a Meso- or even Neoproterozoic age for the Seridó Group. Such an age is difficult to reconcile with the intrusive relations of the $G_{2}$ orthogneisses with regard to the Serido supracrustals. In that case, the tangential $\left(\mathrm{D}_{2}\right)$ structures in the Serido Group should be ascribed to the Brasiliano orogeny, or at least to an event $c a$. 1.0 Ga old, like the one proposed in the Zona Transversal Domain to the south, by Jardim de Sá et al. (1992,1995c), Santos \& Brito Neves (1993), and Campos Neto et al. (1994). One is thus faced with major conflicts around these geochronological and structural data sets.

\section{DISCUSSION OF THE CONFLICTING POINTS}

\section{The G2 Orthogneisses and the Supracrustal Country Rocks: Ages and Stratigraphic Relations}

The geochemical signature of the $G_{2}$ orthogneisses points to an erogenic, syn to late-collisional context for their emplacement (Jardim de Sá 1994, Jardim de Sa et al. 1995a,b), to which the tangential $\mathrm{D}_{2}$ structures are ascribed. Clear intrusive relations with regard to the Jucurutu paragneisses are displayed by xenoliths and apophyses, the same holding (although with some dispute; see also Caby et al. 1995) with the Seridó micaschists. Even if the precision of the $\mathrm{G}_{2}$ dates reported in this paper or in previous contributions may be challenged, their rough agreement (including different methods) makes it difficult to relate these metaplutonics to a younger, Meso- (1.4 to $0.9 \mathrm{Ga}$ ?) or Neoproterozoic event. In the light of gradational, interfingering contacts between the different formations of the Seridó Group (Jardim de Sa 1994), the $1.9 \pm 0.1 \mathrm{Ga}$ dates in the $\mathrm{G}_{2}$ granitoids reported in this paper point to a Paleoproterozoic age for all those supracrustal units. 

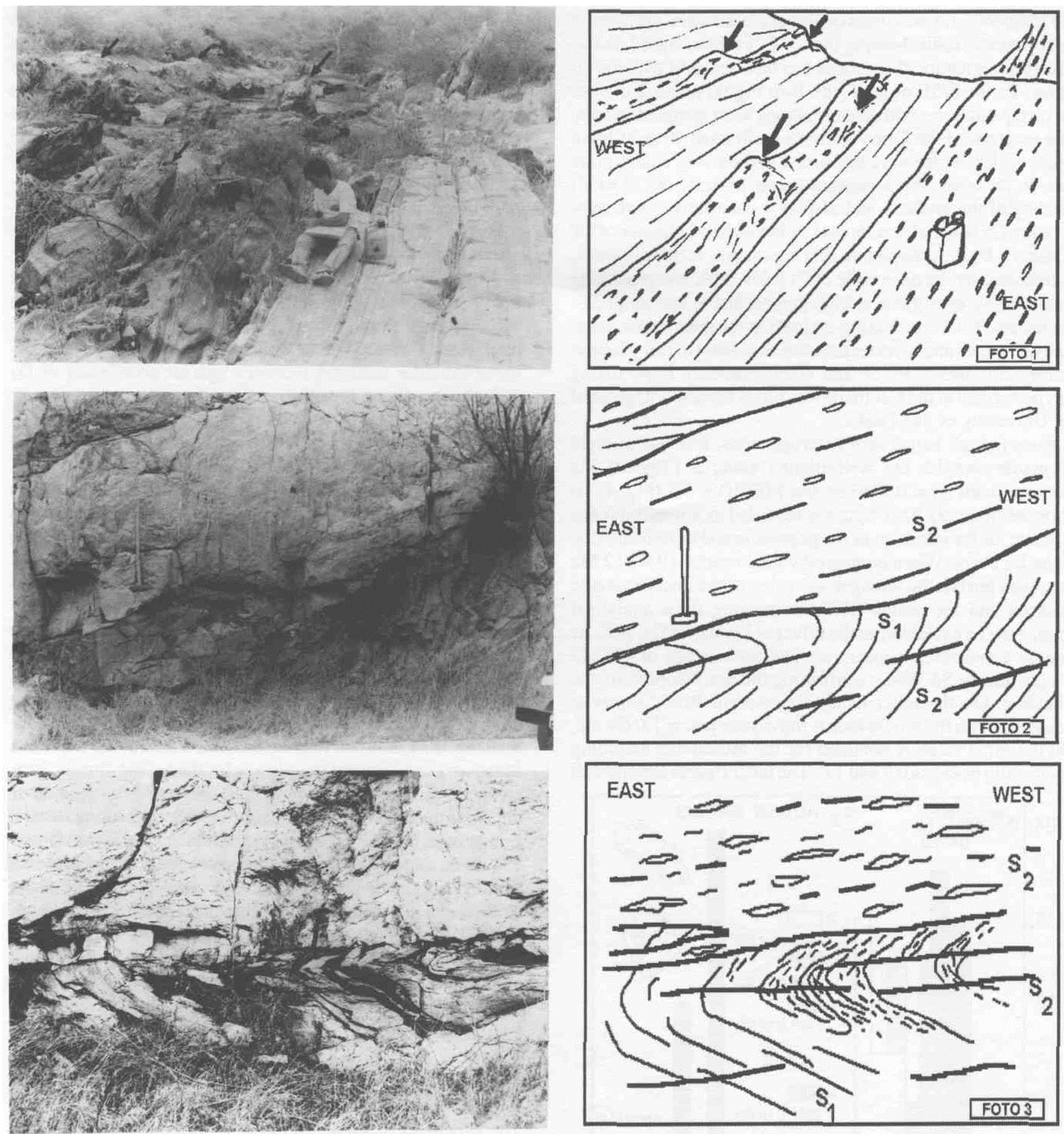

Plate 1. Photo 1 and sketch - Sheared intrusive contact between the $G_{2}$ augen gneiss (light rock in the right pan of the photo) and the Serido micaschists (darker rocks in the left part of the picture), close to Barra de Dois Rios, NE of Cerro Cord. Apophyses of the augen gneiss (shown by arrows) cutting the micaschists are still recognizable. Photo 2 and sketch - $G_{2}$ metapegmatite sheet cutting through the $S_{1}$ gneissic layering of the Caicó Complex, east of Açu. The pegmatite and its foliation are paralell to the axial surface of $F_{2}$ folds in the gneiss, supporting its syntectonic emplacement. Photo 3 and sketch-Detail of the $G_{2}$ metapegmatite sheet in the upper part of the photo, displaying the flat-lying $S_{2}$ foliation, intruded in interleaved amphibolite and orthogneiss of the Caico Complex (lower part of the photo), east of Açu. Once again, the pegmatite and its foliation are parallel to the $F_{2}$ axial surface. Intrafolial $F_{1}$ folds are locally observed.

Prancha 1. Foto 1 e esboço auxiliar -Contato intrusivo cisalhado entre o augen gnaisse $\mathrm{G}_{2}$ (rocha clara na parte direita da foto) e os micaxistos Seridó (rocha mais escura a esquerda na foto), proximo a Barra de Dois Rios, NE de Cerro Cora. Apofises do augen gnaisse (marcadas por setas) cortando o micaxisto ainda são reconhecfveis. Foto 2 e esboso auxiliar - Sheet de metapegmatito $\mathrm{G}_{2}$ truncando o bandamento $\mathrm{S}_{1}$ do gnaisse Caicó a leste de Açu. $\mathrm{O}$ pegmatite e sua foliação são paralelos ao piano axial de dobras Fa nos gnaisses, comprovando seu alojamento sintectonico. Foto 3 e esboço auxiliar - Detalhe de um sheet de metapegmatito $\mathrm{G}_{2}$ na parte superior da foto, com foliafao $\mathrm{S}_{2}$ de baixo angulo, intrusivo em anfibolitos e ortognaisses interfoliados do Complexo Caicó (parte inferior da foto), a leste de $A c ̧ u(R N)$. Mais uma vez, o pegmatito e sua foliacao sao paralelos a superficie axial de dobras $F_{2}$ nos gnaisses. Dobras intrafoliais $F_{1}$ são localmente observadas. 


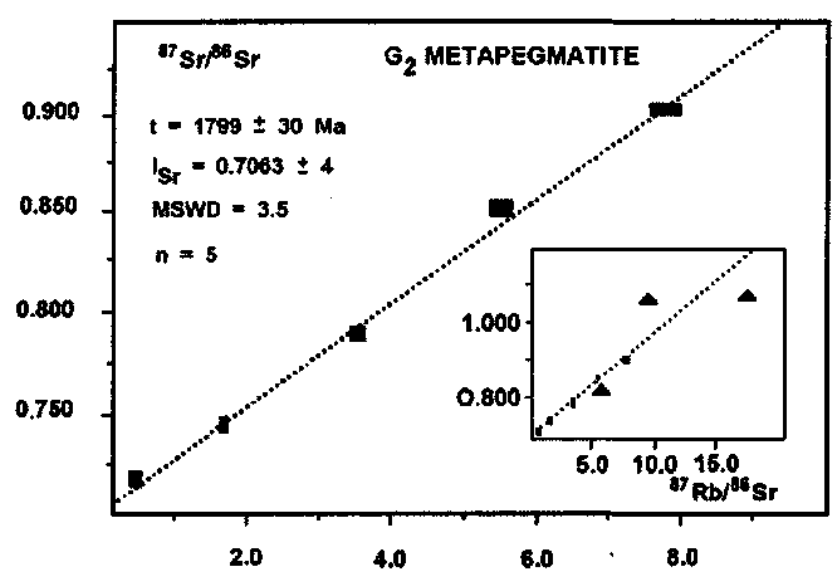

Figure 4 - $R b-S r$ whole rock errorchron of the $G_{2}$ metapegmatites east of $A c ̧ u(R N)$. The cut-off level for the five selected samples is 2.7 ( $1 \delta$ error level). Three additional samples (see inset) were not considered in the calculation. Figura 4 - Errócrona $\mathrm{Rb}-\mathrm{Sr}$ em rocha total dos metapegmatitos $\mathrm{G}_{2}$ a leste de Açu (RN). $O$ nfvel de corte das cinco amostradas consideradas e 2,7 (nivel de erro 15), No inset são mostrados tres ponto adicionais, não considerados no cálculo.

On the other hand, the Nd model dates of the metasediments by Van Schmus et al. (1995a,b), together with a 1.4 Ga Sm-Nd isochron obtained from mafic metavolcanics interlayered with the lower micaschist levels of the Seridó Formation (Jardim de Sá 1994, interpreted as a meaningless mixing line), suggest a maximum 1.7 to $1.4 \mathrm{Ga}$, late Paleoproterozoic to early Mesoproterozoic age for these supracrustals. In this case, the Seridó Group metasediments would be resting, through tectonic or stratigraphic contacts, upon a basement including the Caicó gneisses and the $\mathrm{G}_{2}$ granitoids as well. A pre-Seridó Group age for the $\mathrm{G}_{2}$ orthogneisses would demand that their contacts were entirely of tectonic, allocthonous nature (and not deformed, originally intrusive contacts as we presently consider), what is hard to reconcile with the field relations and the shapes of these plutons (tabular sheets following or truncating at a low angle the basement-cover contacts, for instance). The existence of distinct, older and younger (preand post- $\mathrm{G}_{2}$ ) supracrustal assemblages could remove at least some of these difficulties, but this has yet to be shown.

The Age of the Tangential Structures Except for the high strain, strike-slip mylonitic belts of Brasiliano $\left(\mathrm{D}_{3}\right)$ age, the tangential structures impart a very penetrative fabric in the metasediments, basement gneisses and $\mathrm{G}_{2}$ granitoids. Correlation of this fabric is based on its continuity, in orientation (especially of the stretching lineations) and kinematics, across different areas and units throughout the region (Jardim de Sá 1994, Jardim de Sa \& Fuck 1995). Under this view, the $\mathrm{U}-\mathrm{Pb} 1.96 \mathrm{Ga}$ age obtained by Hackspacher et al. (1995a) on a sphene from Caicó gneisses is consistent with the late Paleoproterozoic age postulated for this reworking event $\left(\mathrm{D}_{2}\right)$. On the other hand, a Meso- to Neoproterozoic age for the Seridó Group would demand the existence of two tangential deformation regimes, the older one (1.9 Ga old) restricted to a basement comprising the Caicó and $\mathrm{G}_{2}$ gneisses, and a younger one present in those metasediments, predating or penecontemporaneous with the strike-slip $\mathrm{D}_{3}$ deformation. Except for flower structures and detachment surfaces associated with strike-slip shear zones (Jardim de Sá et al. 1993, Jardim de Sá 1994), there are no convincing arguments for these two events of tangential deformation, which thus remain hypothetical at present (see Hackspacher et al. 1995b, for instance).

CONCLUDING REMARKS The recent geochronological data reported by Van Schmus et al. (1995a,b) for the Seridó Belt raise a number of problems concerning field relations and the presently accepted tectonostratigraphic framework, implying the occurrence of a number of features which are presently controversial. These include: a) a Neoproterozoic source area, possibly an arc-type terrain, in order to explain the low $\varepsilon_{\mathrm{Nd}}$ values (young $\mathrm{T}_{\mathrm{DM}}$ dates) in the Seridó supracrustals; b) the occurrence of a young (Brasiliano) tangential deformation in these supracrustals, distinct with regard to the one recorded by the basement and $\mathrm{G}_{2}$ gneisses; c) two different supracrustal assemblages, pre- and post- $\mathrm{G}_{2}$ orthogneisses; d) a number of peculiar tectonic contacts, especially at the interface of the $\mathrm{G}_{2}$ plutons and their present country rocks. All such features still require demonstration by apropriate, field structural-stratigraphic data.

Taking into account such problems, one is led to consider other possibilities such as complex isotope systematics and alternative geochronological interpretations. Concerning the $\mathrm{U}-\mathrm{Pb}$ zircon dates $c a$. $700 \mathrm{Ma}$, obtained in the supracrustals near Barra de Santa Rosa (Van Schmus et al. 1995b), some of the samples indeed correspond to Brasiliano granitoid sheets. In the micaschists, affected by high temperature, low pressure syn- $\mathrm{D}_{3}$ metamorphism (sillimanite grade), at least part of the analysed zircons (euhedral, clear and limpid short prisms) could be of metamorphic origin and not detrital grains, being very similar to the ones reported by Toteu et al. (1990) from micaschists in Cameroon. Concerning the $\mathrm{Nd}$ data, an open system isotope evolution (due to volatile fluxing during the Brasiliano event ?) could be tentatively argued in order to produce anomalously young model dates (see Black \& McCulloch 1987, for instance); this is no more speculative than the other interpretations mentioned above, dealing with field geological relations. It is clear that a final answer, if possible, is once more postponed to a future step in the regional research.

Being a penetrative, high-temperature contractional deformation in the $\mathbf{S B}$, the $\mathrm{D}_{2}$ flat-lying structures are interpreted in terms of a collisional event which also involved terranes now exposed in the Nigerian Shield and possibly further north in Central Hoggar (Bertrand \& Jardim de Sá 1990, Jardim de Sa 1994). However, instead of an integral, in situ paleoproterozoic orogenic belt preserving its own tectonic zonation, these polycyclic terranes represent dismembered microcontinents welded together during the Brasiliano orogeny, and possibly also in a previous, $\mathrm{ca}$. $1.0 \mathrm{Ga}$ old orogenic event (Jardim de Sá et al. 1992,1995c, Santos \& Brito Neves 1993, Jardim de Sá 1994). The importance and good preservation of pre-Brasiliano structures in the SB drives attention to the potential preservation of earlier events in the crustal orogenic memory, as stated in many classical and more recent papers (Den Tex 1974, Passchier et al. 1990) but so frequently denied by some workers nowadays.

\section{Acknowledgements FINEP/PADCT, CAPES/CO-}

FECUB, European Economic Comunity/Brazil Scientific Cooperation and $\mathrm{CNPq}$ are acknowledged for finantial support to the authors. W.R. Van Schmus, B.B. Brito Neves and J.M. Sá are thanked for stimulating scientific discussions. 


\section{REFERENCES}

ARCHANJO, C.J. \& BOUCHEZ, J.L. 1991. Le Seridd, une chaine transpressive dextre au Prdterozoique supérieur du Nord-Est du Bresil. Bull. Soc. geol. France, 162: 637-647.

BERTRAND, J.M. \& JARDIM DE SA, E.F. 1990. Where are the EburnianTransamazonian collisional belts ?: Can. Jour. Earth Sci., 27: 13821393.

BLACK, L.P. \& McCULLOCH, M.T. 1987. Evidence for isotopic equilibration of Sm-Nd whole-rock systems in early Archaean crust of Enderby Land, Antarctica. Earth Planet. Sci. Lett, 82: 15-24.

CABY, R. 1989. Precambrian terranes of Benin-Nigeria and Northeast Brazil and the late Proterozoic south Atlantic fit. In: DALLMEYER, R. D. ed. Terranes in the circum-Atlantic Paleozoic orogens. Geol. Soc. Am., Spec. Paper 230: p. 145-158.

CABY, R.; SIAL, A.N.; ARTHAUD, M.H.; VAUCHEZ, A.. 1991. Crustal evolution and the Brasiliano Orogeny in Northeast Brazil. In: DALLMEYER, R.D. \& LECORCHE, J.P. eds. The West African orogens and circum-Atlantic correlatives. Berlin, Springer-Verlag. p. 373397.

CABY, R.; ARTHAUD, M.; ARCHANJO, C.J. 1995. Lithostratigraphy and petrostructural characterization of supracrustal units in the Brasiliano Belt of Northeast Brazil: geodynamic implications. Jour. South Am. Earth Sci., 8: 235-246.

CAMPOS NETO, M.C.; BITTAR, S.M.B.; BRITO NEVES, B.B. 1994. Domfnio tectSnico Rio Pajeu - Provincia Borborema: orogdneses superpostas no Ciclo Brasiliano/Pan-Africano. In: CONOR. BRAS. GEOL., 38. Camboriu, 1994.Anais ...Florianópolis, SBG. v. 1, p. 221-222.

CORSINI, M. 1995. Geometric, cinematique et signification tectonique des systemes de de'crochements ductiles intracontinentaux de la Province Borborema (NE Bn5sil). Geodinam. Acta, 8: 129-141.

CORSINI, M.; VAUCHEZ, A.; ARCHANJO, C.J.; JARDIM DE SÁ, E.F. 1991. Strain transfer at continental scale from a transcurrent shear zone to a transpressional fold belt: the Patos-Seridd system, northeastern Brazil: Geology, 19: 586-589.

DANTAS, E.L.; CORDANI, U.G. VAN SCHMUS, R.W. HACKSPACHER, P.C.; BRITO NEVES, B.B.; NUTMAN, A.P. 1995. Terrenos arqueanos e paleoproterozdicos do macifo Caldas Brandao na Provincia Borborema. In: SIMP. GEOL. NORDESTE, 16. Recife, 1995. Atas... Recife, SBG. v. 2vp. 423-427.

DEN TEX, E. 1974. The polycyclic lithosphere: an attempt to asses its erogenic memory. In: BELLIERE, J. \& DUCHESNE, J.C. eds. Geologie des Domains Cristallins. Soc. gtol.. Belgique. p. 145-182.

GAPAIS, D. 1989. Shear structures within deformed granites: mechanical and thermal indicators: Geology, 17: 1144-1147.

HACKSPACHER, P.C.; DANTAS, E.L.; VAN SCHMUS, W.R. 1995a. Datação do metamorfismo associado \& tectonica colisional Transamazonica - U/Pb em titanita e zircao. In: SIMP. NAC. EST. TECT6NICOS, 5. Gramado, 1995. Atas ...Porto Alegre, SBG, p. 379-381.

HACKSPACHER, P.C.; LEGRAND, J.M.; BRITO NEVES, B.B.; DANTAS, E.L.; VAN SCHMUS, W.R. 1995b. Tectonica de cavalgamento noroeste e escape lateral nordeste/sudoeste durante a colisao Brasiliana no Grupo Seridó - RN. In: SIMP. NAC. EST. TECT6NICOS, 5. Gramado, 1995. Atas ...Porto Alegre, SBG, p. 42-43.

JARDIM DE SA, E.F. 1994. A Faixa Seridó (Província Borborema, NE do Brasil) e o seu significado geodindmico na Cadeia Brasiliana/PanAfricana. Brasilia. 804 p. (Tese de Doutorado, Institute de GeociSncias da Universidade de Brasilia).

JARDIM DE SA, E.F. \& FUCK, R.A. 1995. Regimes deformacionais superimpostos: aplica?ao de critdrios de compatibilidade cinematica na Faixa Seridó, NE do Brasil. In: SIMP. NAC. EST. TECT6NICOS, 5. Gramado, 1995. Atas ...Porto Alegre, SBG, p. 46-47

JARDIM DE SA, E.F.; FUCK, R.A.; LETERRIER, J.; MARTIN, H. SOUZA, Z.S.; MACEDO, M.H.F. 1995a. Geochemistry and geodynamic setting of the Paleoproterozoic Ga granitoids in the Seridd Belt, NE Brazil: synorogenic or rapakivi-type anorogenic intrusions ? In: SYMP. RAPAKIVI GRAN. AND RELATED ROCKS. Bel6m, 1995. Abstr ...Belem, UFPA, p. 46-47.
JARDIM DE SA, E.F.; FUCK, R.A.; MACEDO, M.H.F.; KAWASHITA, K.K.; SOUZA, Z.S.; PEUCAT, J.J. 1995b. Structural and geochronological data bearing on the Paleoproterozoic $\mathrm{G}_{2}$ granitoids in the Seridd Belt, NE Brazil: synorogenic or rapakivi-type anorogenic intrusions ? In: SYMP. RAPAKIVI GRAN. AND RELATED ROCKS. Betem, 1995. Abstr ...Belem, UFPA, p. 48-49.

JARDIM DE SA, E.F.; MACEDO, M.H.F.; FUCK, R.A.; KAWASHITA, K. 1992. Terrenos proterozdicos na Provfncia Borborema e a margem norte do Craton do Sao Francisco. Rev. Bras. Geoc., 22: 472-480.

JARDIM DE SA, E.F.; MACEDO, M.H.F.; FUCK, R.A.; PEUCAT, J.J.; LETERRIER, J.; KAWASHITA, K.; SOUZA, Z.S. 1995c. Granitdides sinorogSnicos ca. 1,0 Ga na Provfncia Borborema, NE do Brasil: dados geoqufmicos e geocronoldgicos. In: SIMP. GEOL. NORDESTE, 16. Recife, 1995. Atas... Recife, SBG. v. 1, p. 162-165.

JARDIM DE SA, E.F.; MACEDO, M.H.F.; LEGRAND, J.M.; MCREATH, I.; GALINDO, A.C.; SA, J.M. 1987. Proterozoic granitoids in a polycyclic setting: the Seridd region, NE Brazil. In: INTERN. SYMP. GRANITES AND ASSOC. MINERALIZ., 1. Salvador, 1987. Ext. Abstr... Salvador, SBG/SGM-BA, p. 103-110.

JARDIM DE SA, E.F.; SOUZA, Z.S.; AMARO, V.E.; HOLLANDA, M.H. B.M. 1993. Estruturas tangenciais relacionadas \& deforma?ao transcorrente: exemplos na porgao oriental da Faixa Seridd. In: SIMP. GEOL. NORDESTE, 15. Natal, 1993. Atas... Recife, SBG, p. 268-271.

KOBER, B. 1986. Whole-grain evaporation for ${ }^{207} \mathrm{~Pb} /{ }^{206} \mathrm{~Pb}$ age investigations on single zircons using a double-filament thermal ion source: Contrib. Mineral. Petrol., 93: 482-490.

LEGRAND, J.M.; LIEGEOIS, J.P.; DEUTSCH, S. 1991. Datacao U/Pb e $\mathrm{Rb} / \mathrm{Sr}$ das rochas precambrianas da regiSo de Caicd. Reavaliagao da definigao de um embasamento arqueano. In: SIMP. GEOL. NORDESTE, 14. Recife, 1991. Atas... Recife, SBG, p. 276-279.

MOORBATH, S. \& TAYLOR, P.M. 1985. Precambrian geochronology and the geological record. In: SNELLING, N. J. ed. The chronology of the geological record. Geol. Soc. London, Mem. 10: p.10-28.

PASSCHIER, C.W.; MYERS, J.S.; KRONER, A. 1990. Field geology of high-grade gneiss terrains. Berlin, Springer-Verlag, $150 \mathrm{p}$.

SANTOS, E.J. \& BRITO NEVES, B.B. 1993. Petrogenesis and tectonic setting of the Lagoa das Pedras magmatism, Floresta, State of Pernambuco, Borborema Province, Northeastern Brazil. An. Acad. Bras. Ciencias, 65: 131-140.

SOUZA, Z.S.; MARTIN, H.; MACEDO, M.H.F.; PEUCAT, J.J.; JARDIM DE SA, E.F. 1993. Un segment de croflte continentale juvenile d'Sge prot6rozoique infe*rieur: le Complexe de Caicd (Rio Grande do Norte, NE-Br\&il). C. R. Acad. Sci. Paris, III, 316: 201-208.

TOTEU, S.F.; MACAUDIERE, J.; BERTRAND, J.M.; DAUTEL, D. 1990. Metamorphic zincons from North Camerooni implications for the PanAfrican evolution of Central Africa. Geol. Rundschau, 79:777-788.

VAN SCHMUS, W.R.; BRITO NEVES, B.B.; HACKSPACHER, P.C.; BABINSKI, M. 1995a. U/Pb and Sm/Nd geochronologic studies of Eastern Borborema Province, Northeastern Brazil: initial conclusions. Jour. South Am. Earth Sci., 8: 267-288.

VAN SCHMUS, W.R.; BRITO NEVES, B.B.; HACKSPACHER, P.C.; BABINSKI, M.; FETTER, A.; DANTAS, E. 1995b. Neoproterozoic and late Mesoproterozoic sedimentary and volcanic sequences in the Borborema Province, NE Brazil. In: SIMP. GEOL. NORDESTE, 16. Recife, 1995. Atas... Recife, SBG. v. 2, p. 391-393.

MANUSCRITO N ${ }^{\circ} 868$

Recebido em 31 de agosto de 1996 Revisao dos autores em 30 de novembro de 1996 Revisao aceita em 15 de Janeiro de 1997 